\title{
Research on the Influence of Network Consumption Based on Credit Platform on College Student's Consumption Behavior
}

\author{
Weiwei Zhang ${ }^{1, a, \dagger}$ Zongzhi Shi ${ }^{2, b, \dagger}$ \\ ${ }^{1}$ Changchun University of Science and Technology, School of Science \\ ${ }^{2}$ The Pennsylvania State University, Smeal College \\ a396902782@qq.com ${ }^{b}$ zs5096@psu.edu. \\ tThese authors contributed equally.
}

\begin{abstract}
With the development of Internet consumption and the popularization of college students' concept of credit consumption, Internet credit loan consumption has become a very common consumption mode among college students who accept new things quickly. This has become a phenomenon that cannot be ignored. Because college students have not formed a mature view of consumption and the supervision of Internet credit consumption is not standardized, this consumption mode has produced some hidden dangers of consumption security, which has brought some pressure and challenge. Therefore, our research uses the literature research method, summarizing method, case study method to analyze the Internet credit development present situation, and taking the Internet consumption behavior of college students based on credit platform as the breakthrough point. Emphatically analyzes the harmfulness of Internet credit from the angle of individual college students, the enterprise platform and the government, and put forward some strategies to optimize the environment Internet consumption and increase the security of college students' Internet credit loan. On this basis, through the study of college students' Internet credit consumption behavior, we provide references and suggestions for guiding college students' rational consumption, standardizing and strengthening the supervision of credit platforms, and optimizing the environment and order of the Internet credit consumption market.
\end{abstract}

Keywords: College Students, Internet Consumption, Credit Loan, Strategy

\section{INTRODUCTION}

With the development of the Internet and the popularization of Internet payment, Internet credit consumption has become the current trend. It aimed at a wide range of users because people from all walks of life can easily access it through the Internet and diversified online consumption. According to the Ministry of Industry and Information statistics, as of December 2018, the number of Internet users in China was 829 million, and 56.53 million new Internet users were added throughout the year. The Internet penetration rate reached 59.6 percent, which increased 3.8 percentage points over the end of 2017. Among them, college students account for $25.4 \%$ of the total number of Internet users, and they are the main users of the network [1]. The college student's age is mainly between $18-21$, which is the age that is easy to induce consumption. Meanwhile, their money source mainly comes from their parents and part- time jobs, which cannot fulfil their consumption level. So, the appearance of $\mathrm{p} 2 \mathrm{p}$ leading provides them a great platform to borrow money and buy things they want From the perspective of a leading platform, they also would like to lend money to those students. Because they have parents, classmates, teachers, friends, and their location is easy to track, compared to workers or businessmen, the college student has much more credit than them. The "Report on Internet Ecology and Consumer Behavior of Chinese College Students in 2018", released by the New Media Data Research Institute of East China University of Political Science and Law, based on the 21829 valid samples, shows that $56.84 \%$ of college students in China had used consumer finance in 2018, which the proportion of Ant Credit Pay, Ants Cash Now, JDBaitiao used was 65.84\%, 24.73\%, and $18.64 \%$ respectively [2]. For college students who account for a large proportion of online consumption, 
loan consumption has become their mainstream consumption mode.

Therefore, it is necessary to study the consumption psychology of Internet credit for college students and college students' consumption trend. Xia Wenjing (2021) finds that the gender of university students and their monthly living expenses are related to their level of recognition and acceptance of Internet instalments. Moreover, she finds that the personal psychological factors, credit purchase motivation, and profit motivation of college students are the main factors that influence the consumption of Internet instalments [3]. Dai Weicai (2017) summed up the three consumption views of college students in the history of Chinese and foreign economic thought: Thrift Consumption View, Extravagant Consumption View, and Moderate Consumption View, and summed up five kinds of college students' bad Internet loan consumption psychology, which are overconsuming consumption psychology, follow-up consumption psychology, comparing consumption psychology, hedonic consumption psychology and showing off consumption psychology [4]. Wang Leyan et al.(2020)analyses the influence of college students' online credit consumption from three aspects: individual, family, and society. They believe that if they fall into a loan repayment crisis for individual college students, it will affect their daily life and academic performance and even mental health. For college students' families, excessive network lending may cause an economic burden on families and destroy family relations. For society, if there is violence to urge debt, it will have a negative impact on society [5].

Based on the conclusion of the article we cited above, we find that the characteristics of Internet credit consumption of Gen $\mathrm{Z}$ college students in China are still worth discussing. Our research will study the characteristics of Internet credit consumption of Gen $\mathrm{Z}$ college students in China through several methodologies. We will advise government, enterprise, and students to discuss how we can utilize the Internet leading and consumption behavior and what we can do to induce the current situation into a more lawful and healthier.

\section{METHODOLOGY}

This article will use the literature research method, summarizing induction, and case study to analyse the college students' consumption behavior and find out the current problem.

The literature research method can help us define the problem through periodical, magazine, industry statistical report, managerial book. Using those data and research results, we can generally make a model of how many percent of college students are having the problem with paying their debts and why they buy things that they cannot afford. After we have a rough estimation of the current problem, we can focus on the students who often use the credit platform and find out a complete psychology process of their consumption behavior. Then we can develop corresponding strategies that help them spend money more rationally. That strategy also works for the lending platform as well, and we can utilize their consumption psychology and make a better promotion against college students.

For the summarizing induction method, we will use the data and theories to conclude the features of the college students and how they differentiate from other consumer groups. Then we will discover the advantage and the disadvantage it brings on the Internet credit platform and the following effect on the mainstream media. For example, how many percent of the Internet lending platforms rely on those students, where this money goes after colleges borrow it, what kinds of industries benefit from them and which group of people is getting hurt in this scenario. After we know all these above, we will divide the conclusion into two parts, and one is the things that we would like to keep as much as possible. Because it is mutually beneficial to the big environment, and it is the one destined output of this industry. Another one is the things that we need to figure out how we induce it to a rational, healthier place, or it is one radically bad phenomenon that we need to work on how to eradicate completely.

For the case study method, we will collect several characteristic instances and use them as samples to explore why a typical Internet credit lending platform is so fit for college students now. It will be based on the characteristics, distribution channel, market strategy, and revenue structure. Also, these cases can provide us a good hindsight of the improvement for the following steps. The sample can come from the news, report, or even our daily life. What is important for those cases is that they have to represent the most typical behavior and its problem to the college students' Internet credit consumption. Through these apparent examples, we can get a good estimation of the Internet lending and get a reliable conclusion of why it happened.

\section{RESULT}

\subsection{Analysis of the Present Situation of College Students' Network Credit Platform}

According to our research, the debt platform for college students can be classified into three types. One is the legal firms that are certified by the government, and they lend money to poor students to help them pay their tuition fees. They have gradually vanished in recent years because more and more students can have direct funding from either school or government. This type of company is the prototype lending company that is aimed on college students. 
Another one is a big firm's leading platform like HuaBei or JDBaitiao. Because their parent company is the most popular online shopping platform in China, they have a huge competitive advantage compared to the other lending platforms. Their main marketing strategy is providing rewards for people who use credit payment when they are buying goods on their platform. Thus, even if students have enough cash to pay their shopping cart, they would rather be using the credit payment method for that tiny payback after getting used to the credit payment and becoming their default payment method. The lending platform will increase their credit step by step as students pay their loans regularly month by month. In this case, the loan amount will soon become a big number and excess ability for college students to pay.

When the students need a large amount of money to cover the debt in a large lending platform, the small and illegal lending firm with the advertisement of "short term", "quickly arrive", "low interest" will be their savior [6]. These illegal firms, without any supervision, usually making a profit by the fraud contract or highly compound interest rate. When students borrow money from them, they have to pay a high handling fee which may take 30 percent of the loan. Also, they will quickly ask for their money back, and the debt may double in weeks. If students cannot afford their debt, those lending companies will call their family, friends or spread their personal information to the Internet as a threat. Many students may even choose to end their life under such stress.

\subsection{Analysis of the Harmfulness of Network Credit Loan -- A Perspective of College Students}

For now, more and more illegal lending platforms are aimed at college students because they do not have enough safety consciousness. With the promotion of induced consumption, like $50 \%$ off today or $60 \%$ off for student accounts, most students cannot refuse that temptation. Since college students do not have any fixed income, they have to borrow from others to meet their own funding needs in the short term. As time goes on, it is easy to cause overdraft consumption habits. After the student gets used to the excessive consumption, it will lead to the inability to repay the loan and affect their normal life and study eventually. One example that perfectly illustrates the harm to college students is the news published in June 2018 [7]. In this case, one college girl stole her mother's property like the watch, phone, and transact money from mom's card while her mother was sleeping. Finally, her mother found the transaction record and sued her in court. Also, her mother dismissed their adoption afterward. It is a tragedy that a young lady has to steal her mother's money to pay her own debt, and the reason that caused this tragedy to happen is the illegal lending platform that induces them to have an unaffordable loan.

\subsection{Analysis of the Harmfulness of Network Credit Loan -- An Enterprise Perspective}

Contributing to their sinister profit model, many legal firms cannot compete with those illegal lending platforms. They will lose their customers during the competition, which falls into a dilemma that bad money drives out good. To survive in such a market, firms that originally follow the rules have to choose either to quit the market or do the dirty trick as those illegal firms do. In the current market of lending platforms, except those large platforms, most of the lending platforms are illegal and need to be supervised. We have to admit that the appearance of those illegal lending platforms is the inevitable output of the market demand, but that does not mean it is natural, and we should keep it as the rules of the free market. The existence of those companies has already affected the normal lending market. If we choose to leave it alone, more and more college students will lose their future, and the environment of the lending market will get worse and worse. Eventually, the lending platform market may leave with few leading firms and countless fraud companies.

\subsection{Analysis of the Harmfulness of Network Credit Loan -- Social Perspective}

From the country's view, the loss of the great college student is absolutely huge. Although it does stimulate the country's GDP in some way, the right way to increase a country's GDP should be the higher level of consumption that caused by the practical increased of the citizens' revenue. In this case, because of the spread of consumerism that is publicized by the media and mainstream, the college students who do not have fixed income choose to borrow money to consume more than he or she can undertake and its cost is the countless bills without any hope. Despite the many disputes of whether consumerism is good or bad, that mind should not become the mainstream among college students that are still in the stage where they need to study and improve themselves. Their mind should not be manipulated by capitalism or any other type of thoughts. We need to give them a choice to get in touch with the things they want to know and choose to believe what they want to believe.

\section{DISCUSSION}

Based on the result mentioned above, we will also discuss the strategies to improve and optimize the current situation of Gen Z college students' Internet credit from three angles of individual students, enterprise or platform, and government. 


\subsection{Individual Students}

\subsubsection{Daily Consumption}

In daily life consumption, higher judgment is considerably beneficial for college students to prevent from being easily seduced by the consumerism on the network and around them, thus avoiding the comparison, blind obedience, and impulse consumption psychology that will cause over-consumption and excessive consumption. When students would like to buy a commodity, they need to consider the practicability and affordability before making decisions. Moreover, students need to take the initiative to learn financial knowledge to establish an independent sense of financial management and form a correct view of value and consumption to use their assets in a planned way. At present, there are many bookkeeping apps for college students to record their consumption level and personal assets in more detail and clearly, such as Daodao Jizhang, Shark Jizhang, and so on. These app have very intelligent functions, for example, they can easily switch between different charts, comprehensive analysis of revenue and expenditure changes, so that users can see their financial situation at a glance[9].

\subsubsection{Credit Consumption}

If college students have to use credit consumption, they should have enough judgment ability to choose the right and safe platform within the range of their repayment ability. If students are threatened or hurt, seeking help from their parents or using the law as a weapon is a better way to protect themselves from a whirlpool of vicious lending.

\subsection{Enterprise/Platform Strategies}

\subsubsection{Optimizing Products}

Credit platforms should think about how to optimize their own products to legally stimulate college students' consumption and solve the financial difficulties of students at the same time to achieve a win-win situation. Credit enterprises or platforms need to do risk assessments in advance and predict college students' consumption level. Enterprises should study the consumption characteristics of college students comprehensively and set appropriate loan quotas, loan interest rates, and loan term according to their repayment ability.

\subsubsection{Loan Security}

To provide college students with a more secure user experience, credit platforms have to reduce the illegal competition and the malicious behavior of inducing college students to over consume. Malicious lending and violent calls should be eradicated, and the platforms should use more legitimate ways to address the root causes of delays in repayment, such as improving the borrower's identity information review, raising the threshold for borrowing, and so on.

\subsection{Government Strategies}

\subsubsection{Legal Regulation}

The government should establish a perfect legal mechanism to promote the construction of an Internet financial, legal system. For instance, using legal documents to regulate college students' loan behavior paves the way for the government to fundamentally solve the problem of insecure credit [8]. It is also necessary to supervise the Internet credit platform more strictly and severely punish illegal Internet loans and fraud. In this way, we could form a strong constraint on the consumption platform and prevent the adverse consequences.

\subsubsection{Auditing Standard}

The government needs to make a correct evaluation of college students' consumption level and consumption habits to control the audit mechanism of credit platforms strictly and formulate higher standards for auditing. Moreover, it is necessary for government to regularly check and clean up the platforms that violate the regulations in time to maintain good Internet market order and bring a pure Internet consumption environment for college students. For example, he Supreme People's Procuratorate issued a notice on illegal lending[10], which provides for legal penalties for such acts.

\subsubsection{University Guidance to College Students}

The government should correctly guide the consumption of college students through universities. One of the most effective methods is to set up basic finance courses to enable students to learn financial knowledge or set up specialized credit consulting rooms to give them more opportunities to understand the relevant knowledge of Internet loans to prevent students from falling into the whirlpool of insecurity. In this regard, the government has taken some effective measures. For example, in September 2016, the Ministry of Education issued a special circular on the development of centralized special education on-campus loan risk prevention. In March 2017, a member of the National Committee of the Chinese People's Political Consultative Conference also proposed the rational and healthy development of campus credit. It shows the harm of "university loan", the urgency of solving it, and the degree of national attention[5]. 


\section{CONCLUSION}

The previous article illustrated the lending platform's current situation and spread them into three types to discover the connection between them. The small illegal lending platform is relied on by college students who cannot afford the large lawful loan company's debt. Then look at the damage of network debt on the college students, enterprise, and social sides. From the student's view, it severely affects young people's valuable college life and even causes them to end their life. From the enterprise perspective, it breaks the loan market rules and threatens the survival of many small but lawful lending companies. The illegal lending platform is like the cancer of the market and drives out many good firms. From the social side, it potentially affects the mainstream college students' thoughts, which is inappropriate for college students that are in a stage of study and improve themselves. In the discussion part, we list several ways to solve the problem and change this industry's current situation. For students, we suggest they use bookkeeping apps to establish the correct consciousness of financial management. When they get threatened by the illegal lending platform, they can seek help from the law or police. The enterprises should stimulate the consumption of their target market morally and avoid malicious inducing advertising. To provide a safety service to college students, the lending firm should stop their violent dunning behavior. For the government, they should establish a better regulation of the network lending platform and strengthen the supervision of the lending company.

This study focuses on the damage of the lending platform on college students, and the further discovery of the other group who get hurt from the network debt and the reason it happened can be the future study. Through the research, the data collected have shown that some of the lending platform's target market group is the postgraduates or interns. They may have different college student issues like the financial stress of rent or the peer pressure. The study on those groups can be a great subject for future research.

\section{REFERENCES}

[1] Statistical report on Internet Development in China, CNNIC, 2019.

[2] Report on Internet Ecology and Consumption Behavior of Chinese College Students in 2018, East China University of Political Science and Law, 2018.

[3] Xia Wenjing, Research on the Period Consumption Behavior of College Students - - In-depth Survey Based on Users of Ant Credit Pay and Jingdongbaitiao, J. Modern Business. 2021(02):2729.
[4] Dai Weicai, Analysis on the Guiding Theory of College Students' Correct Consumption View-_ Taking "University Loan" as an Example, J. Journal of Hebei Normal University (Educational science Edition), 2017,19(05):105-111.

[5] Wang Leyan, Jiang Haoyu, Gao Yang, The Influence and Countermeasure Analysis of College Students' Internet Credit Consumption Behavior under Consumerism, J. Since and Technology Economic Guide,2020,28(33):200-201.

[6] Common Advertisement of Fraud lending firm https://new.qq.com/omn/20210321/20210321A09E CX00.html

[7] News of college girl who stole her mom's money: https://news.163.com/18/0625/11/DL53E6H80001 875P.html

[8] Government Notice of lending firm's regulation: https://news.163.com/18/0625/11/DL53E6H80001 875P.html

[9] Take stock of the annual accounting software. Choose the right one for you to start accounting. J . Computers and Networks, 2017,43(24):34-35.

[10] Opinions of the Supreme People's Court, the Supreme People's Procuratorate, the Ministry of Public Security and the Ministry of Justice on Certain Issues in Handling Criminal Cases of Illegal Lending: https://www.spp.gov.cn/spp/xwfbh/wsfbh/201910/t 20191021_435272.shtml 